\title{
Fatal Misconception: The Struggle to Control World Population
}

\author{
Matthew Connelly \\ Cambridge MA: The Belknap Press of Harvard University Press, 2008 \\ ISBN 978-0-674-02423-6 \\ $\$ 23.16,529$ pages
}

Reviewed by

Kevin McQuillan

University of Calgary

Calgary, Alberta, Canada

Demographers are an insular group. Although often located in departments of sociology or economics, at least in North America, their focus is often tightly trained on very specific issues within their discipline. Despite that, demography has been more involved in the formation and implementation of social policy than most of the social sciences; yet, the demographic literature contains rather few analyses of the relationship between demographic research and the institutions which promoted and executed population policies. It has taken an historian, Matthew Connelly, to write a history of the campaign to reduce fertility and control the growth of the human population. It is harsh reading for demographers. Some of the most famous individuals and leading institutions of our discipline come in for stinging criticism. But it is a story that all demographers and, indeed, any social scientist concerned about the relationship between research and social policy would do well to read.

Connelly has written a sweeping history of efforts aimed at controlling the world's population in the twentieth century based not only on extensive archival research - the staple of historical scholarship - but also on interviews with some of the leading figures. It is a tendentious history that he is written. Connelly is not interested in simply cataloguing the various efforts at fertility reduction but in exposing what he believes was the arrogance and misguided ideas that drove the family planning programs supported by such institutions as USAID, UNFPA, and the International Planned Parenthood Federation. At the core of all these efforts, he argues, was the sense that those directing the programs knew the interests of the poor and illiterate better than they did themselves. The result was programs in which the end - control over world population 
That many efforts at spreading family planning were based on dubious assumptions and sometimes involved little concern for the people who were the "clients" is beyond dispute. The strong connection to the eugenics movement in the earliest phases of the birth control movement and the aggressive character of family planning efforts in countries like India, often fixated on numerical targets for the number of acceptors, are shameful chapters in the history of the family planning movement and professional demographers were often complicit in these programs. Connelly is quick to make retrospective judgments on the morality of the actors, however, often drawing on ideas that might seem obvious today but were not at the time. Promoters of family planning may well have carried what now seem like sexist and racist ideas with them, but they were hardly alone in the period in which they worked. True, a few brave souls were ahead of the pack and rejected these notions, but it is hardly surprising that the majority of those in the family planning movement accepted ideas about the roles of men and women and the advanced character of Western societies that were current at the time. His argument is not strengthened by a disturbing tendency to take cheap shots at some of the unnamed characters in the story concerning their spending patterns and sexual adventures. The stories may well be true but could probably be told about virtually any group of researchers and policy advisors at the time.

In addition to his critique of the ethical dimensions of the family planning movement, he also questions the links among evidence, public debate, and policy. He is critical of both theories of demographic change and the quality of evidence used to support programs designed to reduce fertility. I suspect that many demographers will be struck by the paucity of demographic information in the book and by the limited knowledge of the demographic literature the author possesses. Of course, he is an historian, not a demographer, and the book focuses on the politics of population control not theories of demographic change. Still, his understanding of demographic theories of population change and his sometime simplistic dismissal of demographic research, especially fertility surveys in developing countries, are troubling. He seems completely unaware of historical analyses, such as the influential work of Knodel and Van Ge Walle, that pointed to latent demand for fertility control even in nineteenth century Europe.

Connelly also seems to rely on hindsight to dismiss the concerns of those working on population policies in decades past. As any demographer knows, the rising rate of population growth in the post World War Two period set off alarms about the future. Through the fifties and sixties, each set of population projections was quickly shown to be too conservative. While it is now easy to mock the exaggerated 
claims of a Paul Ehrlich about an oncoming demographic catastrophe, policymakers were legitimately concerned about how societies would cope with unprecedented rates of population growth. Supporters of aggressive programs to reduce fertility can claim, with some justification, that raising the alarm played a role in the transition to lower birth rates. One cannot help but be struck by the similarities with the current debate over global warming. Are those who argue that we face impending catastrophe the modern day counterparts of the population control supporters of the past? Will we look back some day and conclude that proponents of strong measures to reduce global warming, even when such measures may cause immediate harm to populations around the world, were misguided ideologues seeking to impose their world views on others?

Such criticisms aside, I urge all demographers to read this book. Although the argument is often strident and sometimes thinly supported, Connelly raises important questions about the relationship between demographic research and population policy. His advice that policymakers should heed the views of those for whom policies are developed is sound and, if followed, would have helped to avoid the excesses and failures that too often characterized population policies in the past. 